\title{
Pandemi, Bilgiye Erişim ve Akademi
}

\section{Pandemic, Information Retrieval and Academy}

\author{
Ercan Akyol"
}

The COVID-19 pandemic has dramatically changed our lives since it started. Although this change had heavy consequences, it also had positive aspects in terms of access to academic knowledge. Acceleration of digitization processes, online workshops, the expansion of databases and the fact that access to information has become a little cheaper than before has provided an irreversible convenience for the academy. This editorial covers thoughts on related topics.

Değerli Okurlar,

Bitecek, biter, bitti derken bir türlü sonu gelmeyen ve kısa vadede geçecek gibi de görünmeyen bir pandemi sürecinin içinde yaşantımıza devam ediyoruz. Gündelik hayatımızın her anına nüfuz etmiş olan COVID-19'la birlikte yaşama pratiği beraberinde getirdiği stresin ve zorlukların yanı sıra araştırmaları başta kütüphanelere ve arşivlere dayanan sosyal bilimcilerin çalışma biçimini değiştirdi ve değiştirmeye devam ediyor.

Hiç kuşku yok ki önceki dönemin pandemi kısıtlamalarından uzak çalışma koşullarını bugün hâlen arıyoruz. Özellikle benim gibi tarihçiler açısından arşivlere uzun bir süre gidememek pek çok araştırmacı için ilk başlarda nahoş sonuçlara yol açtı. Arşivlerin yanında elbette bir de kütüphanelere gidişin sınırlandırılması var ki açık raf alan kütüphanelerini kullananlar ikincil kaynak görmek ve yayınlardan haberdar olmak için kütüphaneye gitmenin ne derece önemli olduğunu bilirler. Sadece bunlar da değil; odağında insanın yer aldığı "beşerî" bilimlerin merkezi olan kütüphaneler beşerî bilimciyi, tabir-i caizse, insan içine çıkaran, ona üzerine çalıştığı, düşündüğü konuları başkalarıyla tartışabileceği bir ortam sunan ve böylece onu bir "yalnız savaşçı" olmaktan kurtaran da yerlerdir. Özellikle salgının ilk yılında arşiv ya hiç gidilemeyen ya da çok özel izinlerle, güç bela gidilen, kütüphane ise sipariş edilmiş kitabın alıp çıkıldığı bir yer hâline gelmişti. Şu günlerde ise arşivler öngörülmez bir süre için şimdilik açık, kütüphanelerin durumu ise pek değişmedi.

Niyetim baştan sona olumsuz bir tablo çizmek değil, çünkü tüm bu kısıtlamaların sonuçları tamamıyla da olumsuz olmadı. Evet COVID-19 ile kaynaklara ulaşmak bir nebze zorlaştı, ancak özellikle Avrupa'daki akademisyenler için bu yeni bir sorun değil. Bir şirket

\footnotetext{
* Türk Kütüphaneciliği Editörler Kurulu Üyesi. Viyana Üniversitesi, Yakın Doğu Çalışmaları, Viyana, Avusturya.E-posta: ercan.akyol@univie.ac.at

Member of Turkish Librarianship Editorial Board. University of Vienna, Near Eastern Studies, Vienna, Austria. E-mail:ercan.akyol@univie.ac.at
}

Geliş Tarihi - Received: 29.09.2021

Kabul Tarihi - Accepted: 29.09.2021

Yayımlanma Tarihi - Published: 30.09.2021 
gibi işleyen Avrupa üniversitelerindeki sistem, araştırmacıları 2-3 yıllık projelerle istihdam edip sonrasında başından savıp yeni bir iş aramak zorunda bırakıyor. $\mathrm{Bu}$ sistemde akademisyenlerin "tenure" alması, kalıcı bir kadro bulup bir yere yerleşmesi çok az sayıda kişinin sahip olduğu bir ayrıcalık. Kadrolu azınlığın karşı kutbunda ise devasa bir araştırmacı ordusu şehirden şehre birkaç yıllık hatta bazen birkaç aylık projeler için taşınıyor, göç ediyor; sonra aynı stresli iş arama süreci yeniden gündeme geliyor. Sonuç: biteviye bir akademik konar-göçerlik.

İşte bu sebeple henüz COVID-19'la tanışmamışken dahi Avrupa'daki akademikler gerek maddî gerek lojistik koşulların dayatmasıyla kütüphanelere, arşivlere ve belki daha da önemlisi akademik veri tabanlarına ulaşmada sorunlar yaşıyordu. Bu konar-göçer sistemin bir sonucu olarak kişisel inisiyatifle kurulan çok kullanıcılı e-posta/sosyal medya grupları, çeşitli araştırma ağları ve internet sayfaları sayesinde bu sorunların önüne geçilmeye çalışılıyordu. Günümüzde Avrupa'da akademisyenlerin bilimsel literatüre ulaşımı ve aralarındaki bilginin dolaşımı azımsanmayacak ölçüde bu şekilde gerçekleşiyor.

Arşivler ise tamamen olmasa da bu durumun büyük ölçüde dışında kalıyordu. Fakat pandemi ile birlikte bu noktada da bazı değişiklikler meydana geldi. Salgının uzaması sosyal bilimlerde çok daha önceden başlamış olan dijitalleşme sürecini hızlandırdı ve kaynakları daha kolay ve yasal bir şekilde ulaşılabilir hâle getirdi/getiriyor. Avusturya, Almanya, Fransa, Amerika, İtalya ve kısmen İngiltere gibi ülkelerdeki yazma eser koleksiyonlarının açık erişimli dijital veri tabanları gün geçtikçe genişliyor. Türkiye'deki büyük arşivler ise yazma eserlerin erişimi ve tarihi vesikalara ulaşım konusunda pek çok Avrupa ülkesinden çok daha hızlı ve uyumlu bir şekilde bu sürece adapte oldu. Osmanlı araştırmaları için en geniş arşive ev sahipliği yapan T.C. Cumhurbaşkanlığı Devlet Arşivlerine (eski ve araştırmacılar arasında hâlen bilinen adıyla Başbakanlık Osmanlı Arşivleri/BOA) kişisel bilgisayarlardan günün her saatinde ulaşmak mümkün. Benzer şekilde, Süleymaniye vb. arşivlerden online bir başvuru ile bir gün içinde çok sayıda yazma eser temin edilebiliyor. İstanbul Üniversitesi Nadir Eserler Kütüphanesi ise devasa bir yazma eser koleksiyonunu çoktan dijitalize edip herkesin doğrudan erişimine sundu. Araştırmacıların pandemi öncesinde tüm bu arşivlere ulaşması bugünkü kadar kolay değildi. Ödenek bulmak için başvurulan burslar, kimi zaman cepten harcanan paralar, bürokratik engeller ve yapılan seyahatlerin hepsi bilim insanları için ayrı birer zorluk ve zaman kaybıydı. Şurası kesin ki COVID-19 gelmemiş olsa da tüm bu dijitalleşme ve erişim kolaylıkları önümüzdeki yıllarda hayatımızda olacaktı ve olmalıydı da. Pandemi zaten o yöne doğru giden bir trendi hızlandırdı, o kadar.

COVID-19 önlemleri çerçevesinde başka değişiklikler de oldu. Online uygulamalarla konferans, seminer ve atölyelere katılmaya şaşılacak kadar kısa bir sürede hepimiz alıştık. Hatta seyahat ve konaklama ücretlerinin buharlaşıvermesiyle akademik dünya şu anda takip edilmesi mümkün olmayan ve önceden neden düşünülmediğine dair pek çok kişinin hayıflandığına emin olduğum bir konferans karnavalına dönüştü. Bu tip bir araya gelmelerin insan tanımak ve kendini tanıtmak gibi sosyal ve faydalı olduğunu görmezden gelemeyeceğim yönleri var, çünkü kabul edelim ki hiçbir online uygulama ile işin bu kısmı gerçeği gibi yapılamıyor. Ancak bu işlevi bir tarafa bırakacak olursak bilgiye erişim, araştırmalara geri dönüş alma ve güncel durumdan haberdar olma tüm bu online organizasyonlar vasıtasıyla çok daha hızlı, pratik ve külfetsiz gerçekleştirilebiliyor. 
Pandeminin onca olumsuzluğuna rağmen bu süreç bilgiye erişimi hızlandırmada bir katalizör görevi gördü, bazen de başrolü oynadı. Akademide bu kazanımların ne kadarının kalacağını gelecekte hep birlikte göreceğiz. Ancak akademi hâlâ bir yönüyle evrensel olma iddiasını taşıyorsa, açı ve ücretsiz erişim konusundaki gelişmeler korunmalı ve hatta daha da ileri götürülmeli temennisiyle bu konuyu burada noktalıyorum.

\section{Değerli Okurlar,}

Yazarların bilgisel üretimlerinin gerektiği gibi işlenip okura sunulmasında sorumluluk alarak yazar ve okur arasında seçici, geliştirici ve yayınlayıcı rolüyle editörlük görevini işlevsel kılan Editörler Kurulu çalışma arkadaşlarımızın, uzmanlık ürünü doğru bilgisel/bilimsel çalışmayı belirlemek ve okur kitlesini tanıyarak yayımlamak adına editoryal eylemlerini başarıyla yerine getirdiğine inanyoruz. Türk Kütüphaneciliği’nin yolculuğunun birer yolcusu olan ekip arkadaşlarımızın her çalışma metninin başarısı için gösterdiği tutarlılık, netlik ve kesinlik kimi zaman açık kalp ameliyatı titizliğiyle kimi zaman ise küçük estetik dokunuş inceliğiyle kendisini göstermiştir. Bu bağlamda her doğru bilgisel/bilimsel çalışmanın simyası, bazen yüksek enerji ve büyük gerilimler bazen ise güçlü heyecan ve bulaşıcı sevinçler yaratmıştır.

Kısa bir süre önce ülkemizin ve dünyanın en eski mesleki ve bilimsel dergilerinden olan Türk Kütüphaneciliği'nin yakın geçmişine yönelik bir final değerlendirmesi yapılarak dergi yönetimindeki nöbet değişimi hakkında sizlere bilgi verilmişti. Türk Kütüphaneciliği Sorumlu Yazı İşleri Müdürü Dr. M. Tayfun Gülle'nin görevinden ayrılması sonrasında, Türk Kütüphaneciliği dergisinin vizyon ve misyonunu içselleştiren, değer ve hedefleri bağlamında eylem yeteneğini sergileyen Editörler Kurulu üyelerimizden Süreyya Çankırı Yalçınkaya, Müge Akbulut, Neslihan Er-Koçoğlu, Yalçın Yalçınkaya, Ercan Akyol, Meriç Dirik, Elif Öztop, Ebrar Okur ve Ferhan Koraş'ın editörlük görevinden ayrıldıklarını bildirmek isteriz. Gerek uzun yıllar bilgisi ve deneyimiyle emek veren gerekse yeni katılarak enerjisi ve sinerjisiyle dinamizm kazandıran değerli editör arkadaşlarımıza, dergimize verdikleri destek ve sundukları katkı için teşekkür ediyor, akademik ve mesleki yaşamlarında başarılar diliyoruz.

Değerli Okurlarımız,

Birbirinden ilginç bir seçki ve zengin içerikle dikkatlerinize sunduğumuz yeni sayımızı beğeniyle okumanızı temenni ederken Aralık 2021 sayısında yeni umutlar ve gelişmelerle buluşmayı arzuluyoruz.

Saygilarımızla! 